\title{
Effect of alone and tank mix application of herbicides on weed infestation and productivity of kharif Maize (Zea mays $\mathrm{L}$.)
}

\author{
Ghrasiram, Mukesh Kumar*, Vinod Kumar, Mritunjay Kumar and Ranjan Kumar Laik \\ Department of Agronomy, Dr Rajendra Prasad Central Agricultural University, Pusa Samastipur, Bihar - 848125
}

\section{Article history}

Received: 13 Sep., 2020

Revised : 14 Dec., 2020

Accepted: 28 Dec., 2020

\section{Citation}

Ghrasiram, M Kumar, V Kumar, M Kumar and RK Laik 2020. Effect of alone and tank mix application of herbicides on weed infestation and productivity of Kharif Maize (Zea mays L) . Journal of Cereal Research 12(3):264269. http://doi.org/10.25174/25822675/2020/104735

\section{"Corresponding author}

Email: mukesh.agro@gmail.com

(C) Society for Advancement of Wheat and Barley Research

\begin{abstract}
A field trial was conducted during the kharif season at Agricultural Research Farm of Trihut College of Agriculture (TCA) Dholi under the RPCAU Pusa, Samastipur (Bihar) to find out the efficiency of sole and sequential application of herbicides on weeds and productivity of the maize crop. A total of eleven treatments viz: weedy check, topramezone @ 25.2 g ha-1, tembotrione @ $120 \mathrm{~g} \mathrm{ha}^{-1}$, atrazine @ 1 kg ha-1 $f b$ hand weeding at 25 DAS, atrazine@ $0.75 \mathrm{~kg} \mathrm{ha}^{-1} f b$ topramezone@ $25.2 \mathrm{~g}$ ha-1, atrazine $0.75 \mathrm{~kg} f b$ tembotrione $120 \mathrm{~g} \mathrm{ha}^{-1}$, at razine $1.0 \mathrm{~kg} \mathrm{ha}^{-1} f b$ topramezone $25.2 \mathrm{~g} \mathrm{ha}^{-1}$, at razine $1.0 \mathrm{~kg}$ ha $f b$ tembotrione $120 \mathrm{~g} \mathrm{ha}^{-1}$, topramezone $25.2 \mathrm{~g}$ ha- $1+$ at razine @ $0.75 \mathrm{~kg}$ ha- 1 , tembotrione @ 120 $\mathrm{g} \mathrm{ha}^{-1}+$ atrazine @ $0.75 \mathrm{~kg} \mathrm{ha}^{-1}$, weed free were tested in randomized block design with three replication. A total of twelve weed species comprised of four grasses, seven broad leaved weeds and one sedge were recorded in experiment field. The application of atrazine @ $1.0 \mathrm{~kg}$ ha $^{-1} f b$ tembotrione @ $0.120 \mathrm{~kg}$ ha significantly reduced the weed density of grass weeds, broad leaved weeds and total weeds and its dry weight compared to all other weed control treatments. This treatment had weed control efficiency (WCE) of $78 \%$ and weed index $2.7 \%$. Thereby, recorded higher yield attributes and grain yield (6.24 t ha-1), which was at par with weed free $\left(6.42\right.$ tha $\left.^{-1}\right)$. Therefore, it may be concluded that application of at razine @ $1.0 \mathrm{~kg} \mathrm{ha}^{-1} f b$ tembotrione @ $0.120 \mathrm{~kg}$ $\mathrm{ha}^{-1}$ as effective weed control practice for kharif maize.
\end{abstract}

Keywords: atrazine, tembotrione, maize, weeds, grain yield

\section{Introduction}

Maize is an important cereal crop grown for food; feed and industrial purpose in the world and it occupies third position after rice and wheat in India with an area of 9.43 mha producing $27.82 \mathrm{mt}$ (Ministry of Agriculture, Government of India, 2018-19) and contribute nearly $9 \%$ to the national food basket. Maize could be third most popular food crop after wheat and rice to feed ever increasing population of the world, provided the production of maize be sustained and enhanced under current cultivation area. There are many biotic and abiotic constraints to realise potential yield of kharif maize and among them weed is one of the major stress. Weeds compete severely for growth resources like water, nutrients, sunlight and space.They may lead to yield loss from 33 to $50 \%$, if weeds are not controlled properly (Sharma et al., 2000). Maize crop has critical time for weed control between 3-6 weeks of crop duration i.e. time before the maximum canopy covered to smother the weeds (Sharma et al., 2000). The wider row spacing and slow crop growth rate initially, makes maize venerable to weed competition up to six weeks growth period (Nagalakshmi et al., 2006). Thus, to get maximum yield of maize, thorough weed management is needed during the initial six weeks of crop growth i.e. critical period for crop weed competition. Conventional, mechanical and manual hand weeding methods are still popular to control the weed in field but in rainy (kharif) season however, heavy, heavy and continuous rains coupled 
with scarcity of labour render weed control difficult with these methods. Therefore, weed control by herbicide assumes significance in the cultivation of maize in kharif season. Herbicides control the weeds timely and cogently and are also cost effective. As the kharif season maize experiences more than two flushes of weeds, repeated application of herbicides are needed for effective control of weeds. Application of one herbicide or traditional application of herbicides was not sufficient to control weeds in the maize crop (Kumar and Chawla, 2019), use of pre-and post-emergence herbicides or herbicide mixture will make herbicidal weed control more effective and acceptable to farmers. The requirement of sole and sequential application of herbicide is important and would be effective for weed control in maize crop. Pre-emergence application of herbicides will control the weeds up to 25 days and thereafter post-emergence herbicide application after 25 DAS so that further growth of weeds can be checked. Therefore, an experiment was conducted to find out the effect of sole and sequential application and mixture herbicides on weeds in maize during kharifseason.

\section{Material and methods}

A field trial was conducted during the kharif season 2019 at Agricultural Research Farm of, Trihut college of Agriculture (TCA) Dholi under the RPCAU Pusa, Samastipur (Bihar). This site comes under middle Indo Gangatic Plains, lied at 250 99' N latitude, 850 60' E longitude and altitude of 52.18 MSL. The soil was sandy loam soil having sand silt and clay content 65, 20 and $15 \%$, respectively. The soil was alkaline as it has $\mathrm{pH} 7.9$, low in organic carbon $(0.46 \%)$, medium in available $\mathrm{N}$ $\left(238 \mathrm{~kg} \mathrm{ha}^{-1}\right), \mathrm{P}\left(17.4 \mathrm{~kg} \mathrm{ha}^{-1}\right)$ and available K $(126.2 \mathrm{~kg}$ $\left.\mathrm{ha}^{-1}\right)$. During this experimental season, the total annual rainfall was $935.6 \mathrm{~mm}$, which was distributed well during crop growth period and made environment congenial for proper growth of crop. Maximum $(250.6 \mathrm{~mm})$ rainfall received in 39th metrological weeks (24-30 Sep.). The highest maximum temperature was $35.5^{\circ} \mathrm{C}$ and the lowest temperature was $20.7^{\circ} \mathrm{C}$ in July and October, respectively during crop growth period. The experiment was conducted in randomized block design with 11 treatments viz; Weedy check, Topramezone @ 25.2 gha $^{-1}$ as post emergence (PoE) at 25 DAS; Tembotrione @ $0.120 \mathrm{kgha}^{-1}$ as PoE at $25 \mathrm{DAS}$, Atrazine @ $1.0 \mathrm{kgha}^{-1} \mathrm{as}$ Pre-emergence $(\mathrm{PE}) f b$ one hand weeding $(\mathrm{HW})$, Atrazine @ $0.75 \mathrm{kgha}^{-1}$ as PEfbtopramezone @ 25.2 gha-1, Atrazine
@ 1.0kgha-1asPE $f b$ tembotrione@0.120 kgha-1as PoE, Atrazine @ 1.0kgha-1 $f b$ topramezone@ 25.2 gha-1as PoE, Atrazine @ $1.0 \mathrm{kgha}^{-1}$ as PE $f b$ tembotrione@ $0.120 \mathrm{kgha}^{-1}$, Topramezone@ 25.2 gha $^{-1}+$ at razine @ $0.75 \mathrm{kgha}^{-1}$ as PoE at 15 DAS , Tembotrione @ $0.120 \mathrm{kgha}^{-1}+$ at razine @ $0.75 \mathrm{kgha}^{-1}$ as PoE at $15 \mathrm{DAS}$, Weed free. All these treatments were replicated thrice. The maize crop was grown with recommended package and practices except the weed control practices. All the herbicides were applied as per treatment by using knap sack sprayer with flat fan nozzle using $500 \mathrm{~L} \mathrm{ha}^{-1}$ of water. Weed free treatment was achieved by repeated hand weedings. Weed sampled by randomly putting a quadrate of $0.25 \mathrm{~m}^{2}\left(0.5 \times 0.5 \mathrm{~m}^{2}\right)$ in each plot at two spots from 10 rows of maize in $5 \mathrm{~m} \times 4 \mathrm{~m}$ gross plot size. The weeds fall within quadrate counted, recognized and classified in group of sedge, grass and BLWs and the density presented as numbers per $\mathrm{m}^{2}$. Thereafter, weeds were uprooted, sundried and kept in oven at $60-65^{\circ} \mathrm{C}$ temperature for 48 hours for complete drying till constant weight for its dry weight. The WCE was determined on the basis of weed dry biomass to compare the effectiveness of treatment towards weed control.

The calculation of WCE was done by using the following formula (Das, 2008)

\section{(WDWc-WDWt)}

Weed control efficiency $(\mathrm{WCE})=\frac{\text { WDWc }}{\text { Where, }}$
WDWc $=$ Weed dry biomass/weight $\left(\mathrm{g} / \mathrm{m}^{2}\right)$ in weedy check plot
WDWt $=$ Weed dry biomass/weight $\left(\mathrm{g} / \mathrm{m}^{2}\right)$ in treated plot

Weedindex (WI): The WI determines the percentage loss in crop yield caused by weed competition in comparison to weed free plot(Das, 2008)

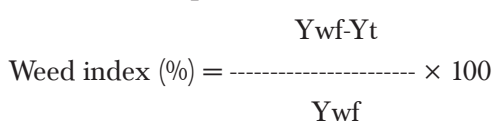

Where,

Ywf $=$ Yield recorded from the weed free

$\mathrm{Yt}=$ Yield recorded from treated plot for which WI needs to be calculated

The five plants were randomly selected from each plot for yield attributes. Net plot area $(3 \times 3 \mathrm{~m})$ was harvested for estimating grain and straw yield of crop. 
The data on different weed and crop parameters was analysed with the help of ANOVA technique for randomized block design. To normalize the data on weed density and weed dry weight, square root transformation $\sqrt{(\mathrm{x}+0.5)}$ was done before analysis. The least square difference (LSD) post hoc was applied for pair wise comparison at $P<0.05$

\section{Results and discussion}

\subsection{Weed flora}

A total of twelve weed species observed in the experimental field, of which four were grasses, viz., Digitaria sanguinalisL., Sorghum helepense L. Brachiaria reptans L., Dactylocteniumaegyptium L.; seven were BLWs viz., Digera arvensis L., Commelina benghalensis L., Cleome viscose L., Euphorbia hirta L.,Boerhavia erecta, Celosia argentea $L$ and Ipomea pestigrand is and only one species of sedge viz., Cyperus rotundusL. The grassy weeds were dominant with relative density $(\mathrm{RD})$ of $42 \%$ followed by BLW with $\mathrm{RD}$ of $33 \%$ and sedge with $\mathrm{RD}$ of $25 \%$ in the control plot (unweeded)of experimental field at 75 DAS.

\subsection{Effects on weed density and its dry weight:}

Significant effect of all weed control treatments on weeds was observed compared to weedy check at 75 DAS. (Table 1). All treatments reduced density and dry weight of weeds as compared to weedy check. At razine @ $1.0 \mathrm{~kg} \mathrm{ha}{ }^{-1} f b$ tembotrione @ $0.120 \mathrm{~kg} \mathrm{ha}^{-1}$ significantly reduced the sedge, BLW) and grass weed density and thus total weed density compared to all other treatments. The second best treatment was atrazine @ $1.0 \mathrm{~kg} \mathrm{ha}^{-1} f b$ topramezone @ $25.2 \mathrm{~g} \mathrm{ha}^{-1}$ which recorded lower weed density compared with remaining all treatments. Sole application of topramezone@ $25.2 \mathrm{~g} \mathrm{ha}^{-1}$ and tembotrione @ $0.120 \mathrm{~kg} \mathrm{ha}^{-1}$ did not effectively control all weeds compared to sequential application with atrazine @ $1 \mathrm{~kg}$ $\mathrm{ha}^{-1}$. By reducing the weed density at razine @ $1.0 \mathrm{~kg}$ ha ${ }^{1} f b$ tembotrione @ $0.120 \mathrm{~kg} \mathrm{ha}^{-1}$ significantly reduced the total weed dry weight compared to all other treatments. Sequential application of atrazine @ $1.0 \mathrm{~kg} \mathrm{ha}{ }^{-1}$ with topramezone @ $25.2 \mathrm{~g} \mathrm{ha}^{-1}$ and tembotrione @ $0.120 \mathrm{~kg}$ ha ${ }^{-1}$ was superior in reducing weed dry weight compared to topramezone @ $25.2 \mathrm{~g} \mathrm{ha}^{-1}$ and tembotrione @ 0.120 $\mathrm{kg} \mathrm{ha}^{-1}$ applied alone. Application of herbicides alone did not decrease the wide spectrum of weeds emanating in several flushes, rather it controlled only single flushes of weeds. Sequential application controlled the second and third flushes of weeds, which means it has controlled the new emerged weeds thus reduced crop weed competition. Varshitha et al. (2019) reported the best results of sequential application of herbicides in kharifmaize. These results also corroborate the findings of Yadav et al. (2018). Rao et al. (2016) also recorded the lowest weed index 13.9\% and $18.1 \%$ compare to weedy check $(45.8 \%)$. They reported that unweeded field reduced $45.8 \%$ maize kernel yield.

\subsection{Effect on weed control efficiency (WCE) and weed index (WI)}

The highest WCE $(78.1 \%)$ was recorded with atrazine1.0kg ha $^{-1} f b$ tembotrione $120 \mathrm{~g} / \mathrm{ha}$ at $75 \mathrm{DAS}$. Sequential application of tembotrione @ $0.120 \mathrm{~kg} / \mathrm{ha}$ with atrazine was observed higher weed control efficiency compared to topramezone with atrazine as a sequential form. The WCE directly indicated the impact of herbicide/treatments on weeds. Sequential application controlled different flushes of weeds therefore recorded higher WCE compared to other treatments. The highest weed index (WI) i.e. 57.6 was recorded with weedy check indicate that if weeds are not controlled the reduction in crop yield may go up to 57.6 $\%$. The lowest WI was recorded (2.7) with application of atrazine @ 1.0kg ha-1 fbtembotrione @ $120 \mathrm{~g} / \mathrm{ha}$ at 25 DAS. The sole application of topramezone and tembotrione recorded higher weed index compared to tank mixed of both herbicides with atrazine $0.75 \mathrm{~kg} \mathrm{ha}^{-1}$ because in tank mix application of herbicides as early post emergence, it has no longer effect on second and third flushes of weed those emerg after 25 to 30 DAS. Similar results were reported by Verma et al. (2018), Nazreen et al. (2018) and Singh et al. (2017).

\subsection{Effect on yield attributes and yield}

Significant improvement in grain yield of maize was observed under different weed control treatments compared to weedy check (Table 2). The highest cob girth $(14.4 \mathrm{~cm})$ recorded with weed free and it was at par on atrazine @ $1.0 \mathrm{~kg} \mathrm{ha-1} f b$ tembotrione @ $0.120 \mathrm{~kg}$ ha $^{-1}$ after 25 days sowing $(14.1 \mathrm{~cm})$. The significantly lowest cob girth was recorded with weedy check from the all chemically treated plots but tank mix applied herbicides also recorded lowest cob girth from the weed free and sequential application herbicides. The highest cob length obtained in the weed free $(16.6 \mathrm{~cm})$ and it was at par on atrazine @ 1.0kg ha-1 $f b$ tembotrione @ $0.120 \mathrm{~kg} \mathrm{ha}^{-1}$ after 25 days sowing $(15.8 \mathrm{~cm})$. Remaining all other treatments 
Table 1 Herbicides effect on weed density, weed dry weight, weed control efficiency (WCE)and weed index (WI) at 75 DAS

\begin{tabular}{|c|c|c|c|c|c|c|c|}
\hline Treatments & $\begin{array}{l}\text { Sedge } \\
\left(\mathrm{m}^{-2}\right)\end{array}$ & $\underset{\left(\mathrm{m}^{-2}\right)}{\text { Broad leaf }}$ & Grassy $(\mathrm{m} / 2)$ & $\begin{array}{l}\text { Total weed } \\
\left(\mathrm{m}^{-2}\right)\end{array}$ & $\begin{array}{l}\text { Weed dry } \\
\text { weight (g/ } \\
\left.\mathrm{m}^{2}\right)\end{array}$ & WCE $(\%)$ & $\begin{array}{l}\text { Weed } \\
\text { index }(\%)\end{array}$ \\
\hline T1- Weedy check & $\begin{array}{l}8.75 \\
(76.3) \#\end{array}$ & $\begin{array}{l}8.4 \\
(70.3)\end{array}$ & $\begin{array}{l}9.36 \\
(87.3)\end{array}$ & $\begin{array}{l}15.3 \\
(234.0)\end{array}$ & $\begin{array}{l}13.25 \\
(175.3)\end{array}$ & 0.0 & 57.5 \\
\hline T2- Topramezone $25.2 \mathrm{~g} \mathrm{ha}^{-1}$ at $25 \mathrm{DAS}$ & $\begin{array}{l}5.63 \\
(31.3)\end{array}$ & $\begin{array}{l}4.99 \\
(24.6)\end{array}$ & $\begin{array}{l}6.55 \\
(42.6)\end{array}$ & $\begin{array}{l}9.94 \\
(98.6)\end{array}$ & $\begin{array}{l}9.27 \\
(85.6)\end{array}$ & 51.1 & 38.3 \\
\hline T3- Tembotrione $0.120 \mathrm{~kg} \mathrm{ha}^{-1}$ at $25 \mathrm{DAS}$ & $\begin{array}{l}5.36 \\
(28.3)\end{array}$ & $\begin{array}{l}4.66 \\
(21.3)\end{array}$ & $\begin{array}{l}6.05 \\
(36.3)\end{array}$ & $\begin{array}{c}9.29 \\
(86.0)\end{array}$ & $\begin{array}{l}8.12 \\
(65.6)\end{array}$ & 62.5 & 23.1 \\
\hline $\begin{array}{l}\text { T4- Atrazine } 1.0 \mathrm{~kg} \mathrm{ha}^{-1}(\mathrm{PE}) \text { fbone hand weeding at } \\
25 \text { DAS }\end{array}$ & $\begin{array}{l}4.32 \\
(18.3)\end{array}$ & 4.01 & $\begin{array}{l}5.2 \\
(26.6)\end{array}$ & $\begin{array}{l}7.81 \\
(60.6)\end{array}$ & $\begin{array}{l}6.83 \\
(46.3)\end{array}$ & 73.5 & 10.0 \\
\hline $\begin{array}{l}\text { T5-Atrazine } 0.75 \mathrm{~kg} \mathrm{ha}^{-1}(\mathrm{PE}) \text { fbtopramezone } 25.2 \mathrm{~g} \\
\text { ha }^{-1} \text { at } 25 \text { DAS }\end{array}$ & $\begin{array}{l}4.76 \\
(22.3)\end{array}$ & 4.57 & $\begin{array}{l}5.66 \\
(31.6)\end{array}$ & $\begin{array}{c}8.65 \\
(74.6)\end{array}$ & $\begin{array}{l}7.14 \\
(50.6)\end{array}$ & 71.1 & 29.2 \\
\hline $\begin{array}{l}\text { T6- Atrazine } 0.75 \mathrm{~kg} \mathrm{ha}^{-1}(\mathrm{PE}) \text { fbtembotrione } 0.120 \\
\mathrm{~kg}^{-1} \mathrm{ha}^{-1} \text { at } 25 \mathrm{DAS}\end{array}$ & $\begin{array}{l}4.07 \\
(16.3)\end{array}$ & $\begin{array}{l}4.07 \\
(16.3)\end{array}$ & $\begin{array}{l}5.36 \\
(28.6)\end{array}$ & $\begin{array}{l}7.84 \\
(61.3)\end{array}$ & $\begin{array}{l}6.93 \\
(47.6)\end{array}$ & 72.7 & 10.6 \\
\hline $\begin{array}{l}\text { T7- Atrazine } 1.0 \mathrm{~kg} \mathrm{ha}^{-1}(\mathrm{PE}) \text { fbtopramezone } 25.2 \mathrm{~g} \\
\text { ha }^{-1} \text { at } 25 \text { DAS }\end{array}$ & $\begin{array}{l}4.21 \\
(17.3)\end{array}$ & $\begin{array}{l}3.70 \\
(13.3)\end{array}$ & $\begin{array}{l}5.23 \\
(27.3)\end{array}$ & $\begin{array}{c}7.63 \\
(58.0)\end{array}$ & 7.75 & 65.9 & 12.8 \\
\hline $\begin{array}{l}\text { T8- Atrazine } 1.0 \mathrm{~kg} \mathrm{ha}^{-1}(\mathrm{PE}) \text { fbtembotrione } 0.120 \mathrm{~kg} \\
\text { ha }^{-1} \text { at } 25 \mathrm{DAS}\end{array}$ & $\begin{array}{l}3.61 \\
(12.6)\end{array}$ & $\begin{array}{l}3.12 \\
(9.33)\end{array}$ & $\begin{array}{l}4.66 \\
(21.33)\end{array}$ & $\begin{array}{l}6.52 \\
(43.3)\end{array}$ & $\begin{array}{l}6.22 \\
(38.3)\end{array}$ & 78.1 & 2.7 \\
\hline $\begin{array}{l}\text { T9- Topramezone } 25.2 \mathrm{~g} \mathrm{ha}^{-1}+\text { Atrazine } 0.75 \mathrm{~kg} \mathrm{ha}^{-1} \\
\text { at } 15 \mathrm{DAS}\end{array}$ & $\begin{array}{l}5.33 \\
(28.3)\end{array}$ & $\begin{array}{l}4.43 \\
(19.3)\end{array}$ & 7.00 & $\begin{array}{c}9.67 \\
(93.3)\end{array}$ & $\begin{array}{l}8.03 \\
(64.3)\end{array}$ & 63.3 & 31.2 \\
\hline $\begin{array}{l}\text { T10- Tembotrione } 0.120 \mathrm{~kg} \mathrm{ha}^{-1}+\text { Atrazine } 0.75 \mathrm{~kg} \\
\mathrm{ha}^{-1} \text { at } 15 \text { DAS }\end{array}$ & $\begin{array}{l}5.06 \\
(25.3)\end{array}$ & $\begin{array}{l}4.12 \\
(16.6)\end{array}$ & $\begin{array}{l}6.58 \\
(41.3)\end{array}$ & $\begin{array}{l}9.1 \\
(83.3)\end{array}$ & 7.48 & 68.2 & 20.5 \\
\hline T11- Weed free check & $\begin{array}{l}0.71 \\
(0.0)\end{array}$ & $\begin{array}{l}0.71 \\
(0.0)\end{array}$ & $\begin{array}{l}0.71 \\
(0.0)\end{array}$ & $\begin{array}{l}0.71 \\
(0.0)\end{array}$ & $\begin{array}{l}0.71 \\
(0.0)\end{array}$ & 100 & 00.0 \\
\hline $\operatorname{SEm}( \pm)$ & 0.14 & 0.11 & 0.14 & 0.21 & 0.08 & ---- & -- \\
\hline $\operatorname{LSD}(\mathrm{P}<0.05)$ & 0.42 & 0.35 & 0.42 & 0.65 & 0.24 & ---- & -- \\
\hline
\end{tabular}

\#Weed data was transformed by square root transformed $\sqrt{ }(\mathrm{x}+0.5)$. The value $\mathrm{n}$ in parentsheses is original value.

Table 2: Effect of herbicides on yield attributes characters, grain and straw yield of maize

\begin{tabular}{|c|c|c|c|c|c|c|c|}
\hline Treatments & $\begin{array}{l}\text { Cob girth } \\
(\mathrm{cm})\end{array}$ & $\begin{array}{l}\text { Cob length } \\
(\mathrm{cm})\end{array}$ & $\begin{array}{l}\text { Grain per } \\
\text { cob }\end{array}$ & $\begin{array}{l}100 \text { seed } \\
\text { weight }(g)\end{array}$ & $\begin{array}{l}\text { Grain yield } \\
(\mathrm{t} \text { ha- } 1)\end{array}$ & $\begin{array}{l}\text { Straw yield } \\
(\mathrm{t} \text { ha- } 1)\end{array}$ & $\begin{array}{l}\text { Harvest } \\
\text { index }\end{array}$ \\
\hline T1: Weedy check & 10.9 & 11.3 & 195 & 16.9 & 2.72 & 3.90 & 0.41 \\
\hline T2 :Topramezone $25.2 \mathrm{~g}$ ha- 1 at 25 DAS & 12.1 & 12.4 & 253 & 19.1 & 3.95 & 5.55 & 0.41 \\
\hline T3: Tembotrione $0.120 \mathrm{~kg}$ ha-1at 25 DAS & 13.1 & 14.2 & 292 & 20.2 & 4.94 & 6.96 & 0.41 \\
\hline $\begin{array}{l}\text { T4:Atrazine } 1.0 \mathrm{~kg} \mathrm{ha}^{-1}(\mathrm{PE}) \text { fbone hand weed- } \\
\text { ing (HW) at } 25 \mathrm{DAS}\end{array}$ & 13.4 & 14.5 & 303 & 21.3 & 5.77 & 7.97 & 0.42 \\
\hline $\begin{array}{l}\text { T5:Atrazine } 0.7 \mathrm{~kg} \mathrm{ha}^{-1}(\mathrm{PE}) f b \text { topramezone } \\
25.2 \mathrm{~g} \mathrm{ha}^{-1} \text { at } 25 \mathrm{DAS}^{-}\end{array}$ & 13.2 & 13.5 & 271 & 19.7 & 4.54 & 6.08 & 0.42 \\
\hline $\begin{array}{l}\text { T6:Atrazine } 0.75 \mathrm{~kg} \mathrm{ha}^{-1}(\mathrm{PE}) f b \text { tembotrione } \\
0.120 \mathrm{~kg} \mathrm{~h}^{-1} \text { at } 25 \mathrm{DAS}^{2}\end{array}$ & 13.4 & 14.9 & 299 & 21.2 & 5.73 & 7.97 & 0.41 \\
\hline $\begin{array}{l}\text { T7 : Atrazine } 1.0 \mathrm{~kg} \mathrm{ha}^{-1}(\mathrm{PE}) \text { fbtopramezone } \\
25.2 \mathrm{~g} \mathrm{ha}^{-1} \text { at } 25 \mathrm{DAS}\end{array}$ & 13.1 & 14.1 & 312 & 20.8 & 5.69 & 7.60 & 0.42 \\
\hline $\begin{array}{l}\text { T8:Atrazine } 1.0 \mathrm{~kg} \mathrm{ha}^{-1}(\mathrm{PE}) f b \text { tembotrione } \\
0.120 \mathrm{~kg} \text { ha-1 at } 25 \text { DAS }\end{array}$ & 14.1 & 15.8 & 314 & 23.3 & 6.24 & 8.61 & 0.42 \\
\hline $\begin{array}{l}\text { T9:Topramezone } 25.2 \mathrm{~g} \mathrm{ha}^{-1}+\text { Atrazine } 0.75 \\
\mathrm{~kg} \mathrm{ha}^{-1} \text { at } 15 \text { DAS }\end{array}$ & 12.5 & 13.1 & 271 & 19.0 & 4.41 & 6.21 & 0.41 \\
\hline $\begin{array}{l}\text { T10:Tembotrione } 0.120 \mathrm{~kg} \mathrm{ha}^{-1}+\text { Atrazine } 0.75 \\
\mathrm{~kg} \text { ha-1 at } 15 \text { DAS }\end{array}$ & 12.9 & 13.8 & 283 & 19.9 & 5.09 & 7.08 & 0.41 \\
\hline T11 :Weed free check & 14.4 & 16.6 & 319 & 24.2 & 6.42 & 8.79 & 0.42 \\
\hline $\operatorname{SEm}( \pm)$ & 0.27 & 0.28 & 8.71 & 0.53 & 0.048 & 0.055 & 0.06 \\
\hline $\operatorname{LSD}(\mathrm{P}<0.05)$ & 0.81 & 0.87 & 26.2 & 1.61 & 0.15 & 0.16 & NS \\
\hline
\end{tabular}


had at par cob length but significantly higher than weedy check and topramezone @ $25.2 \mathrm{~g} \mathrm{ha}^{-1}$ applied alone. The maximum grains/cob found with weed free (319), it was at par with atrazine @ 1.0kg ha-1 fb tembotrione @ $0.120 \mathrm{~kg}$ ha $^{-1}(314)$, atrazine @1.0kg ha-1 $f b$ topramezone @ 25.2g ha $^{-1}$ after 25 days sowing (312), atrazine @ 1.0kg ha-1 fb HW after 25 days sowing was recorded (303)and atrazine @ $0.75 \mathrm{~kg} \mathrm{ha}^{-1} f b$ tembotrione @ $0.120 \mathrm{~kg} \mathrm{ha}^{-1}$ at $25 \mathrm{DAS}$ ( 312). Weed free obtained the highest grain yield $\left(6.42\right.$ tha $\left.^{-1}\right)$ and weedy check recorded lowest $\left(2.72 \mathrm{t} \mathrm{ha}^{-1}\right)$.Atrazine @ $1.0 \mathrm{~kg}$ ha $^{-1} f b$ tembotrione @ 0.120 kg ha ${ }^{-1}$ at 25 DAS recorded significantly higher grain yield $\left(6.24 \mathrm{t} \mathrm{ha}^{-1}\right)$ compared to all other herbicidal treatments. The grain of maize with atrazine@ 1 kg/ha $f b \mathrm{HW}$ at 25 DAS (5.77 t ha-1) was significantly higher from the weedy check but grain yield with atrazine @ 0.75 kg ha ${ }^{-1} f b$ tembotrione @ 0.120 kg ha-1 (5.73 t ha ${ }^{-1}$ ) and atrazine @ 1.0 kg ha ${ }^{-1} f b$ topramezone @ $25.2 \mathrm{~g} \mathrm{ha}^{-1}\left(5.69 \mathrm{t} \mathrm{ha}^{-1}\right)$ were at par with atrazine @ $1.0 \mathrm{~kg}$ $\mathrm{ha}^{-1} \mathrm{fb} \mathrm{HW}$ at 25 DAS. Application of atrazine @ $1.0 \mathrm{~kg}$ ha ${ }^{-1} f b$ tembotrione @ 0.120 kgha $^{-1}$ was recorded 56.39 \% higher than the yield of unweeded plot but $57.61 \%$ higher in weed free plot. The straw yield followed the similar trend as grain yield. Weed control treatments did not significantly influence the harvest index but the highest values were recorded underweed free $(0.42)$, atrazine @ $1.0 \mathrm{~kg}$ ha ${ }^{1} f b$ tembotrione @ $0.120 \mathrm{~kg}$ ha ${ }^{1}$ after 25 days sowing (0.42), atrazine@1.0kg ha ${ }^{1} f b \mathrm{HW}$ after 25 days sowing (0.42) and atrazine @ $0.75 \mathrm{~kg}$ ha ${ }^{1} \mathrm{fb}$ tembotrione $0.120 \mathrm{~kg} \mathrm{ha}{ }^{1}(0.42)$. Atrazine @ $1.0 \mathrm{~kg}$ ha ${ }^{1} f b$ tembotrione @ $0.120 \mathrm{~kg} \mathrm{ha}^{-1}$ after 25 days of sowing increased cob length, cobs per plant, grains per cob and seed weight over other treatments because it provided weed competition free environment for crop to grow and develop. The maximum values of these yield attributing characters

\section{References:}

1. Shaiks N, D Subramanyam, N Sunitha and V Umamahesh. 2018. Growth and yield of maize as influenced by sequential application of herbicides. International Journal of Current Microbiology and Applied Sciences 7: 2319-7706

2. RR Prasad and Venkateswarlu. 2016.Assesment of different herbicides on yield and economics of kharif

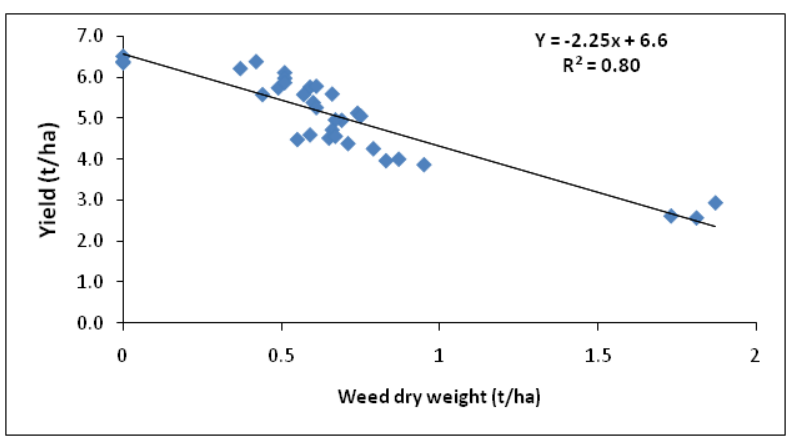

Fig 1: Relationship between weed dry weight and grain yield

might be due to better uptake of nutrients and moisture, leading to translocation of more photosynthates to sink from source under atrazine @ 1.0 kg ha-1 $f b$ tembotrione @ $0.120 \mathrm{~kg} \mathrm{ha}^{-1}$. Related findings were also observed by Singh et al. (2012). Mitra et al. (2018) also found that cob length, grains per cob and 100-grain weight were significantly higher under post-emergence application of tembotrione herbicide as a sequential form when compared to sole and combination applied of herbicides. Singh et al. (2017) also reported similar findings.

\subsection{Regression analysis of weed dry weight and reduction in crop yield}

The relationship between data of weed dry weight and yield was developed by regression analysis taking $\mathrm{Y}$ (Yield as dependent variable) and $\mathrm{X}$ (weed dry weight as independent variable) (Fig.1). The regression equation was $\mathrm{Y}=-2.25 \mathrm{X}+6.6\left(\mathrm{R}^{2}=0.80\right)$. This indicates that increase in weed dry weight by $1 \mathrm{t} /$ ha there will be $2.25 \mathrm{t} /$ ha decrease in crop yield with coefficient of determination $\left(\mathrm{R}^{2}=80 \%\right)$.

From the study conducted it may be concluded that kharif maize have mixed weed flora which reduced crop yield up to $57.6 \%$. Application of atrazine $1.0 \mathrm{~kg} \mathrm{ha}^{-1} \mathrm{fb}$ tembotrione $0.120 \mathrm{~kg} \mathrm{ha}^{-1}$ at $25 \mathrm{DAS}$ can effectively control the weeds and thereby increase the grain yield of maize.

Maize. International Journal of Agricultural Science and Research 6: 409-414.

3. Sharma AR, AS Toor and HS Sur. 2000. Effect of intercultural operations and scheduling of atrazine application on weed control and productivity of rainfed maize (Zea mays) in Shiwalik foothills of Punjab. Indian Journal of Agricultural Sciences 70(11): 757-761. 
4. Kumar M and JS Chawla. 2019. Comparative study on weed control efficacy of different pre-and postemergence herbicides in Kharif maize. Indian Journal of Weed Science 51(1): 32-35.

5. Das TK. 2008.Weed Science: Basics and Application. Jain Brothers Pub, New Delhi, 1st Ed. pp 901.

6. Mitra B, PM Bhattacharya, A Ghosh, K Patra, AK Chowdhury and MK Gathala. 2018. Herbicide options for effective weed management in zero-till maize. Indian Journal of Weed Science 50(2): 137-141.

7. Nagalakshmi KVV, K Chandrasekhar and G Subbaiah. 2006. Weed management for efficient use of nitrogen in maize. The Andhra Agricultural Journal. 53(1\&2): 14- 16 .

8. Singh V, M Ankush Chand and SS Punia. 2017. Study on yield and yield attributes of maize as affected by application of different herbicides. Journal of Pharmacognosy and Phytochemistry 6(5): 2328-2332
9. Singh VP, SK Guru, A Kumar, A Banga and N Tripathi. 2012. Bio-efficacy of tembotrione against mixed weed complex in maize. Indian Journal of Weed Science 44(1): 1-5,

10. Varshitha V, R Babu, PJ Nirmalnath, AM Jamadar, and M Roopashree. 2019.Effect of Early Post Emergent Herbicides Mixtures on Weed Control and Soil Biological Activity in Maize. International Journal of Current Microbiology and Applied Sciences 8: 2319-7706

11. Verma K, KJaysawal, A Maurya, S Kumar, K Yadav, and V Pratap. 2018. Bio-Efficacy of tembotrione $34.4 \%$ SC on diverse weed flora and productivity of Kharif Maize. International Journal of Agriculture, Environment and Biotechnology : 771-775, Special Issue

12. Yadav DB, A Yadav, SS Punia and A Duhan. 2018. Tembotrione for post-emergence control of complex weed flora in maize. Indian Journal of Weed Science 50(2): 133-136 